Pre-proof of article published in Early Medieval Europe 25.1 (2017) 19-37.

\title{
Surrogate fathers: imaginary dialogue and patristic culture in late antiquity
}

\section{Robin Whelan}

Christians in late antiquity did much of their best debating in their opponents' absence. As a mode of polemical argumentation, imaginary dialogue is ubiquitous in late-antique Christian literature. Disputants were prone to reinvent rivals in the texts they wrote against them. ${ }^{1}$ The refutation of heretical opponents entailed imagining (and deviously mischaracterising) their views, before delivering a response. Virtual dialogue was thus the essential mode of polemical exegesis: he/they say this (which is wrong); in response, I/we say that (which is right). This dialogue could be performed: in sermons, virtuosic preachers conjured religious deviants and acted out their refutation, voicing both their own role and that of their opponents. ${ }^{2}$ Even 'real' faceto-face debates could proceed in a similar manner. When Christians had the opportunity (or misfortune) to meet their opponents in person, they tended to debate not so much with that actual Christian as the heretical image of him they had constructed. This was both because of the agonistic character of such encounters, and because it was the most direct means to assimilate that opponent to available categories of heresy. ${ }^{3}$

Virtual dialogue was even prevalent as a literary genre. From the second century at the latest, Christians wrote two-handers with religious opponents; anti-heretical 
dialogues proliferate in late antiquity. ${ }^{4}$ An impressive roll-call of prominent churchmen wrote polemical dialogues with fictitious Christian debaters: Jerome, Rufinus of Aquileia, Cyril of Alexandria, Nestorius, Theodoret of Cyrrhus. These heresiological texts make an important contribution to recent debates on the possibilities of dialogue in early Christianity. The repeated recourse of late-antique Christian writers to virtual dialogue as both genre and argumentative praxis implies a need to revisit the view-advanced in the introduction to an important recent volume edited by Simon Goldhill-that 'early Christianity appears to have little time for dialogue'. ${ }^{5}$ The particular proliferation of these texts also seems to cut against the argument-made by Richard Lim in a series of influential studies-that fifth-century developments in the institutional culture of the church rendered dialogue unattractive for Christians, both as a social activity and a literary form. ${ }^{6}$ Lim is surely right that Christians found open-ended dialogue ideologically fraught because it sat awkwardly with their claims to possess a single religious truth. Nevertheless, the production of heresiological dialogues in that very century by controversialists like Nestorius, Cyril and Theodoret suggests that the growing use of patristic citations and florilegia still left space for creative literary dialogue.

As Averil Cameron and Peter Van Nuffelen have persuasively argued, rather than seeing the rise of the church as causing 'the end of dialogue in antiquity', it is better to see it as provoking the development of new, culturally contingent forms of dialogue. ${ }^{7}$ This article will explore one of those forms: the imaginary heresiological debates in which numerous ecclesiastical controversialists involved their Christian opponents. It seeks to account for the prevalence of this particular form in contexts of Christian controversy, in spite of a patristic culture which would seem, at first glance, 
to preclude such creative invention. These texts developed their own tropes, and show clear links to the ways in which dialogue was used in various other forms of Christian writing and speech acts. It is my contention that they are worthy of study as a genre in their own right.

Dialogues with heresy

Imaginary polemical dialogues took many different forms. Sometimes, writers simply cut and pasted the text of a rival, adding their own commentary by way of response, chapter-by-chapter or line-by-line. ${ }^{8}$ More often, they invented the interlocutors' speech. They set out these conversations like the minutes of a debate encounter or church council ('X said this'; 'Y said that'). Authors show varying inventiveness in setting the scene for these fictive debates. Some used a simple framework with stock characters: many of Cyril of Alexandria's dialogues take place between 'A' and 'B' (representing the bishop and a presbyter, Hermias); likewise, the discussions in the Pseudo-Athanasian dialogues against the Anomoians and Macedonians involve 'Orthodox', 'Anomoian' and 'Macedonian'. 'The discussions in the most basic texts often simply represented a series of statements and responses with little syntactic connection. In this way, such dialogues shade off into the contemporary genre of question-and-answer literature (erotapokriseis) which has received numerous excellent recent studies. ${ }^{10}$

Others dressed up their debates with far more elaborate scenarios. They chose individuals who resonated as symbolic representatives of particular versions of Christian teaching. Literary dialogues paired historic champions of specific orthodox doctrines with the heretics they had incorrigibly denounced: Athanasius and Arius; 
Augustine and his opponents; Cyril and Nestorius. ${ }^{11}$ Authors also invented characters as foils for their orthodox protagonists. They used judge characters who observed protocol and laid down judgements. ${ }^{12}$ Books were framed as individual 'days' of debate: towards the end of a section, the competitors comment on their weariness, the fading light and their resolve to resume the next day. ${ }^{13}$ These debaters even use the insults hurled on such occasions, accusing one another of blasphemy, timewasting and irrelevance. ${ }^{14}$ The setting of these dialogues may not have been as congenial as a symposiastic dinner party, but it was equally self-conscious: the sense of tone this (generally more bracing) atmosphere provided was just as crucial. Whatever the (frequent) authorial protestations to the contrary, heresiological dialogue was no less literary than any other form of ancient dialogue.

These dialogues have tended to be neglected, in part, because of the perception that they are doubly divorced from 'real' debate and dialogue. They are seen as poor relations both to genuine public disputations between Christians, their co-religionists and religious rivals, and to the ancient philosophical texts which better suit modern conceptions of what dialogue is, or should be. They were certainly not dialogic in the modern-or classical Greek-sense in which Lim deploys that adjective. ${ }^{15}$ They did not present open-ended discussion between multiple parties whose differing views were accepted as legitimate in their expression. At the same time, as the excellent papers in The End of Dialogue in Antiquity suggest, the extent to which classical philosophical dialogues were 'open' or 'closed' varied from text to text and even individual texts could be envisioned as 'oscillating between the two poles' ${ }^{16}$ Heresiological dialogues were closer to the 'closed' end of that spectrum than most, but the difference between those Christian works and the more dogmatic symposia was one of degree. Moreover, 
works like the Phaedrus, Hortensius and Saturnalia inevitably fail the other demand most frequently made of 'real' dialogue. They were not the stenographic records of genuine conversations; nor, indeed, were they co-written by their protagonists. As a result, they were the product, not of a plurality of voices, but a single author's imagination. ${ }^{17}$ On those terms, all such authored dialogues were monologic, insofar as the reader heard only one voice which ventriloquised those of others. ${ }^{18}$

It does not seem helpful to measure these texts against an external (and perhaps unattainable) standard of 'real' dialogue-a project rendered all the more difficult by the overlapping and conflicting meanings the word possesses. ${ }^{19}$ At the same time, the contrast between literary dialogues and the records of genuine disputations is not entirely false. The writing of a fictitious controversial dialogue had distinct implications, which the rest of this article will investigate. This is not to detach these texts from the broader historiographical question of how and why Christians did dialogue in the post-classical world. On the contrary, it is an attempt better to understand the privileged perspective these texts offer. Such literary creations show how Christian writers and their imagined audiences thought dialogue between Christians was supposed to go, or at least how, regrettably, they expected it would. Just as the real conversations of erudite symposiasts had been mimicked and modelled by philosophically-minded authors in classical antiquity, ${ }^{20}$ so Christian writers in late antiquity wrote dialogues which both reflected and helped to create a distinctive culture of controversial religious debate. Far from symbolising the end of dialogue in antiquity, these texts helped to perpetuate it.

\section{Dialogue and communication}


As a literary form, dialogue was far from incompatible with the quest for uniformity often cited as a cause for its (perceived) early Christian neglect. The prefaces and contents of heresiological dialogues show their authors intended them as contributions towards the resolution of 'real' controversial debates. In the preface to his Dialogue Against the Arians, Sabellians and Photinians, Vigilius, a late fifth-century African Nicene cleric (and later bishop of Thapsa in the province of Byzacena) laid out a representative set of justifications.

When I was taking a great deal of time discussing the true faith with myself, and I was seeking from consideration of Scripture how I might refute the numerous questions of the heretics with a brief response, (...) it appeared useful and greatly fitting that I might introduce the character of each heretic with his own professed doctrines, as if they were discussing with one another in person. And lest the arguments of each of them might cause doubt with noone examining them, I have made a certain judge, by the name of Probus, to carry out the office of judicial authority. Through his commendable discernment regarding each of them, the intention of pious depravity may be brought to naught. Therefore I have introduced Sabellius, Photinus, Arius and, for our party, Athanasius, so that the truth, refined by the greatest contest of combatants, might reach the notice of all... ${ }^{21}$

In considering why late-antique Christian writers used dialogue, Vigilius' repeated emphasis on distinction and discernment seems telling. The capacity of dialogue to bring clarity to doctrinal debates was a frequent authorial justification. ${ }^{22}$ Personifying orthodoxy and different heresies as two or more Christians debating with one another 
enabled Vigilius and others to distinguish and classify different strands of Christian thought, a set of strategies central to Christian heresiology and identity formation. ${ }^{23}$ Recent perceptive investigations have elucidated how clerics delineated the boundaries of correct Christianity and thus sought to define (their) Christians as a social group. ${ }^{24}$ In its personification of Christian error, heresiological dialogue contributed to that process. In fact, Vigilius' express intention in writing a dialogue was the grand design of bringing 'the truth... to the notice of all'.

Vigilius' expansive intended audience suggests that, contrary to what might be expected of a genre which had represented a 'boutique literary form' in antiquity (to quote Richard Lim), ${ }^{25}$ contemporaries thought dialogue could be adapted for the mass communication which the Christian message required. Writers showed a selfconscious devotion to a wider readership, often using the classic early Christian contrast between their simple speech for ordinary people and the elitist complexities of dialectic. ${ }^{26}$ In the prologue to his dialogue Eranistes, Theodoret, the mid-fifth century bishop of Cyrrhus in Syria, stated that he had deliberately adapted the formatting from earlier Greek dialogues to make it easier to tell who was speaking. ${ }^{27}$ No sweeping statement can be made on how far dialogue writers honoured such commitments. Whatever their desires for brevity and clarity-and concerns about readers losing patience ${ }^{28}$-it is hard to escape the sense that they sometimes indulged in shows of Christian erudition. Vigilius' 'brief response' takes up sixty columns of the Patrologia Latina. At the very least, the frequency with which Christians engaged imagined heretics in dialogue for the benefit of their audiences should caution against seeing this literary form as detached. Most notably, virtual dialogue was a recurrent feature of late-antique sermons, as Christian preachers sought to convey crucial 
differences between their true faith and the views of heretics. ${ }^{29}$ The role that such dialogue played in the most basic (and arduous) of a bishop's pastoral duties, preaching, suggests that dialogue could not simply be a luxury item. ${ }^{30}$ Christian clerics also had to offer it off the peg.

The dialogue form served a clear didactic purpose for late-antique churchmen and exegetes. Like contemporary question-and-answer texts, heresiological dialogues modelled the answers which readers could give to heretical questions and theological conundrums. ${ }^{31}$ They went further, seeking to persuade readers of the rectitude of their teachings, by staging the refutation of alternative views. As Richard Lim has nicely suggested for Augustine's (genuine) debates with Manichaeans, the mere fact of the bishop's victory and the existence of the notarized minutes which recorded it could bolster his congregation, whether or not they understood his arguments. ${ }^{32}$ The same could be said for texts written in the style of those set-piece confrontations.

For readers who paid closer attention, the malleability of imaginary debates permitted precise statements of similarity and difference. Most writers were primarily concerned to put forward their own doctrines and show how they both differed from and could defeat alternative arguments. At the same time, they also emphasized shared teachings; some even sought to demonstrate that 'heretical' views could prove aspects of orthodox doctrine. ${ }^{33}$ Representatives of competing Christological and Trinitarian positions frequently drew on the same body of thought; the cause of their hostilities tended to reside in fine semantic distinctions. To distinguish orthodoxy from heresy often meant first showing what aspects of an opponent's teachings could be accepted, so that the unwary neither allowed 
themselves to be persuaded by their similarity to orthodox views, nor rejected them out of a misguided scepticism (thus falling into an opposite error). So, Theodoret's dialogue begins with cordial discussion between his antagonists over increasingly complicated questions of Christian belief, before they finally reach subjects which divide them. ${ }^{34}$ This seemingly sympathetic approach to a competing viewpoint was not about open-endedness or a desire (as in Cicero's academic dialogues) to leave the reader to judge. The dialogue form nevertheless provided added value: the use of an additional persona made precision easier for Theodoret than in a univocal doctrinal tractate. The flexibility of the dialogue form allowed subtle heresiological claims to be made.

One further (if generally unstated) advantage which might reasonably be deduced is quite simply the opportunity to invent. In contrast to a real public encounter or even a written response to a theological treatise, the writing of a dialogue provided considerable latitude to authors to characterize controversial debates as they understood them and wished others to perceive them. Of course, the critical, even hostile readership heresiological dialogues could receive meant that their writers could not have things all their own way. Christian authors had to take into account the likelihood that they would be read by other clerics involved in contemporary ecclesiastical controversy. The vagaries of ancient methods of 'publication' did not allow writers close control over their texts' circulation. ${ }^{35}$ Dialogues could find their way to individuals less than sympathetic to their authors' doctrinal standpoint or personal integrity; they could even be read by those whom they were intended to attack. Certain authors at least paid lip service to the desirability of this result, articulating a wish to help their victims. Theodoret explained his purpose as to 
debate with them [sc. his opponents] a little, both for the sake of curing them and by way of concern for those who are healthy'. ${ }^{36}$ The sometimes rather blunt use of abusive heresiological terminology within these dialogues might suggest that they would not have gone down well with those who did not share the author's confessional leanings. Whether or not he wished those Christians to be persuaded by his text, he certainly had to consider the consequences if they read it.

The efforts of dialogue authors to cater for such varied constituencies drew on the same basic persuasive techniques. As Yves-Michel Perrin has convincingly argued, heresiological polemic inhered in the process of teaching Christians about correct doctrine and practice. ${ }^{37}$ It thus does not seem helpful, at least when speaking in general terms, to separate the purposes of these dialogues (or late-antique heresiological writings more broadly) into particular categories like teaching or controversy, apologetic or polemic, or the targeting of in- or out-group members. ${ }^{38}$ In any case, these categories were not always clear-cut in the heat of ecclesiastical controversy, where alliances were often fragile and disputes could arise between individuals who might otherwise have perceived each other as members of the same church. The potentially heterogeneous audience of these heresiological dialogues has important consequences for how they should be read. Dialogue authors like Vigilius and Theodoret had to try to satisfy the requirements of both their most erudite colleagues and their humblest congregants. They also had to proof themselves against a wide spectrum of opinion, from the most sympathetic of their supporters to the most hostile of their rivals. The literariness of their dialogues gave them leeway; it did not give them a free hand. 


\section{Speaking in character}

In the early 370s, an Antiochene presbyter, Diodore (later bishop of Tarsus), sent two versions of a (now lost) heresiological dialogue for Basil of Caesarea to peruse. ${ }^{39}$ In his response, Basil stated his preference for the simplicity of the second text, which kept to theological issues, over the first, which involved polemical exchanges between the participants. His concerns about this personal abuse were both ethical and practical. While Basil did not rule out its efficacy, if directed against 'some personage whom all

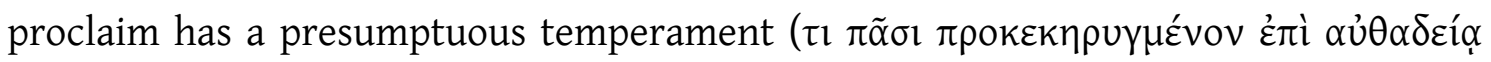

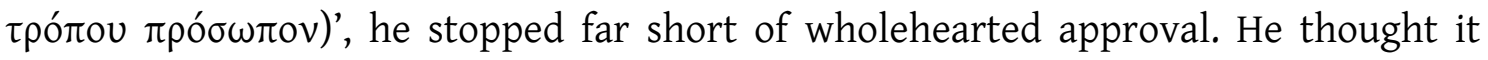

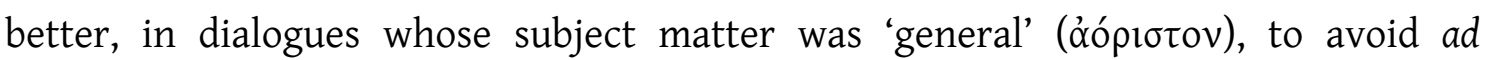
hominem digressions which disrupted the flow. For Basil, delving into the character of the participants was both distracting and morally questionable.

If appropriate characterisation had always been a key feature of classical dialogue ${ }^{40}$ it gained an additional urgency in the context of Christian controversy. The ethical dimension of Basil's anxiety was a necessary consideration: dialogue writers often needed to refute contemporaries they perceived as erring. Yet this posed a ticklish problem: how to rebuke publicly another member of a community whose interpersonal relations were supposed to be governed by love and charity. ${ }^{41}$ If the tone of that rebuke was not appropriately modulated, there was a danger that the author himself could appear as the contentious (and thus potentially deviant) party. In the prologue to the Dialogue of Atticus and Critobulus (generally known by a misleading modern title, the Dialogue against the Pelagians), Jerome caustically complained about the reputation his refutation of named opponents had brought him. ${ }^{42}$ Recalling brushes with Helvidius, Jovinian, Rufinus and Palladius, Jerome rebutted accusations 
that his attacks had been motivated by a hate-fuelled envy (inuidia). The uncomfortably aggressive texts Jerome listed were not dialogues; Christian polemic in all genres struggled to correct fellow Christians appropriately. Nevertheless, dialogue increased this difficulty; indeed, Jerome's prefatory retrospective was explicitly designed to forestall such allegations in the case of the Dialogue. Writing in other genres, Christian authors more emollient than Jerome could remain decidedly vague about the proponents of errant views; in a dialogue, a character had to articulate them. It might be suggested that the introduction of the individual personalities who championed particular views was a much more lively (and potentially much more efficacious) means to articulate Christian doctrine than carefully couched passive constructions. Jerome's pre-emptive response and Basil's critical appraisal suggest that not all would have taken that view.

The problems with naming names did not end with concerns about literary practice and communal behaviour. An indignant response from early sixth-century Africa shows the obvious problem the explicit involvement of a contemporary posed. In his (now fragmentary) ten-book response to a (now lost) dialogue written by a rival named Fabianus, Fulgentius of Ruspe bemoaned, 'I neither said nor thought those things which you saw fit to put under my name in fake minutes. ${ }^{43}$ By inventing speech under Fulgentius' name, Fabianus laid himself open to an easy retort in an argumentative culture which prized accurate verbatim citation. Even authors who were more conscientious in their quotation practices could draw accusations of dishonesty from the opponents whose works they expurgated. Such texts created the appearance of a face-to-face exchange which had never taken place. It turned a response into a two-way conversation, without offering the involuntary interlocutor 
the right of reply he would have received. Few took kindly to this methodology; most, like Fulgentius, sought to set record straight, in a manner which threatened the efficacy of the text and the literary authority of its writer. ${ }^{44}$ The inclusion of individuals who could, in reality, answer back required artful stage management.

As a consequence, authors more often than not hid their real targets (none too subtly) behind invented or historical heretical characters. Such a tactic had obvious advantages beyond plausible deniability. It gave writers leeway to depart from the intended sense of their opponents' views. They could make their opponents' stand-ins articulate the logical consequences of those views as perceived by the unsympathetic author, and thus elide them with the content of pre-existent heresies. In Eranistes and the Book of Heracleides, Theodoret and Nestorius constructed heretical interlocutors (Eranistes and Sophronius) whose views combined multiple errors. In Theodoret's case, this even informed the name of his dupe: 'Eranistes', the 'collector' or 'beggar' ${ }^{45}$ Nonetheless, central to the doctrines that both Sophronius and Eranistes espoused were the views of Cyril of Alexandria and his followers, which were thus associated with a plethora of other heresies, including Apollinarianism, Arianism and Manichaeism. ${ }^{46}$ Learned readers would spot the contemporaries who inspired these heretical shape-shifters. At the same time, those opponents could not complain without drawing attention to the awkward doctrinal similarities the dialogue had identified. Bringing them out into the open would do much of the author's work for him.

For similar reasons, Christian writers rarely appeared as themselves. The protagonist's inevitable victory had the potential to seem self-aggrandising. In the 
preface to the Dialogue of Atticus and Critobulus, Jerome laid out his precautions. 'So that all may assent that I do not hate men, but their errors, and do not seek to defame anyone... I have employed the names Atticus and Critobulus, through whom I might explain what both our party and that of our opponents think ${ }^{37}$ Other writers took similar steps to avoid criticism: as noted above, numerous dialogues involved an individual called 'Orthodox' and one who personified either heresy in general or a specific error. Earlier in his career, Jerome had himself written a Debate between the Luciferian and the Orthodox starring the (fictitious) 'Helladius the Luciferian' and 'Orthodox'; ${ }^{48}$ Theodoret's avatar in Eranistes also bore that name. ${ }^{49}$ Dialogue writers also orchestrated debates between totemic historical figures. By using symbolic characters, they took a step back from contemporary ecclesiastical politics.

These alternatives had the advantage of signalling a greater humility on the part of the author than a straightforward self-portrayal as a champion of orthodoxy. Nonetheless, in their own way they invoked perhaps even greater claims. When Vigilius of Thapsa (for example) put his own doctrines in the mouth of 'Athanasius', he suggested that he could accurately represent the words of that church father; he effectively set himself up as a new Athanasius. Jerome in his Debate between the Luciferian and the Orthodox and Theodoret in his Eranistes were similarly selfaggrandising: in attributing their own positions to individuals called 'Orthodox', they portrayed themselves as representing a pure form of Christian thought that all rightminded individuals should follow. In these dialogues, even when studiously absent, the (authoritative) writer was always present. 
Late-antique dialogue authors shared Basil of Caesarea's concern about deploying particular personalities. Yet they do not seem to have agreed with Basil's evaluation of the effects of making character central to the discussions they invented. Writers used the tone of the conversations and the dynamics of the relationship between the participants to make arguments about particular teachings and those who professed them. These conversations could also model the reader's own responses. Far from being a distraction, the foregrounding of defined characters could be crucial to the communication of orthodoxy.

As part of their didactic purpose, heresiological dialogues could offer exemplary accounts of Christian education. The exchanges between the protagonists could be construed as those of a teacher and pupil: a setup which makes some less sophisticated dialogues resemble erotapokriseis, with 'Question' and 'Answer' simply personified. Cyril of Alexandria's Dialogues present harmonious discussions between Cyril ('A') and his presbyter Hermias ('B'); the recipients of their heresiological attacks remain off-stage. ${ }^{50}$ The inquiring but supportive statements which 'B' makes throughout seem to identify him as a proxy for the (ideal) reader. Other dialogue writers decided to portray more antagonistic relationships: an understandable choice, especially when one party was characterized as orthodox and the other, heretical. Within these more polarized dialogues, there were still means to include the audience in the action. In Vigilius of Thapsa's Dialogue, the pointedly named judge, Probus, stood in for the reader. As Patrizia Guidi has rightly noted, Probus presents himself at the beginning of the text as a catechumen seeking the participants' instruction. ${ }^{51}$ Through consideration of their arguments, the judge gains increasingly sophisticated knowledge of Trinitarian doctrine, until he is won over by Athanasius. Probus' final 
speech is both a judicial verdict and a Nicene profession of faith.$^{52}$ It is difficult not to see in this progression a message for Vigilius' imagined audience. They too were to share in the probity of his fictive judge.

The interpersonal relationships on show were crucial for the writer's ability to explain the status of particular strands of Christian thought and the individuals or groups who supported them. Vigilius' and Theodoret's dialogues begin with cosy back-slapping when the debaters discuss points of consensus, which descends into acrimony when they reach items of divergence..$^{53}$ The plot of the dialogue could be used to help readers understand contemporary ecclesiastical politics. Some writers granted victory to the orthodox, with the submission of the heretic as his pupil. The result was something of a counter-factual. By acknowledging the truth of orthodoxy, the imagined antagonist had done what the real adherents of that particular heresy should (but were perhaps loath to) do.

Most striking in this regard is Jerome's Dialogue against the Luciferians where, after hostile opening forays, Orthodox and Helladius decide self-consciously to switch from polemic to the discourse of a master and student..$^{54}$ Jerome seems to model not just how an orthodox Christian should argue with Luciferian schismatics, but also how those dissidents would ideally respond: by rejoining (his) Catholic Church. Helladius' final statement even has this pliable schismatic explain away the likely response of real Luciferians. 'You should not think that you are the only victor: we have won! The palm goes to both of us: you have beaten me, and I have beaten error. (...) But I confess one thing to you, because I know all too well the customs of my comrades: they will be more easily defeated than persuaded. ${ }^{55}$ If Catholics were unable to convince 
Luciferians in real debates, the audience should put this down to schismatic stubbornness. Sincere, but misguided Christians like Helladius could not fail to be won over by the arguments of those like Jerome.

Other imaginary deviants remained unrepentant. Vigilius' Arius ends his debate convinced of the illegitimacy of the proceedings, which had unsurprisingly ended in Athanasius' victory. Arius bemoaned the 'magical arts' by which his opponent had hoodwinked the judge; he thus resolved to seek the emperor's judgement (iudicium principis) ${ }^{56}$ Given the heresiarch's reputation as an almost demonic enemy of Nicene orthodoxy, such recalcitrance might seem a natural choice. Yet it was not inevitable: a plausibly fifth-century Greek dialogue has Arius cede to Athanasius. ${ }^{57}$ Vigilius' decision to end the text in this way likely stemmed at least partly from contemporary ecclesiastical politics in Africa, where Homoian Christians had the support of the ruling Vandal kings. ${ }^{58}$ Refusing his Athanasius (and his Nicene readers) the satisfaction of a humbled Arius allowed Vigilius to explain away the political support and ecclesiastical ascendancy of contemporaries he saw as Arians. If those Arians remained steadfast in their doctrinal affiliation, this was because, like the founder of their heresy, they were implacable in the face of its clear disproof. In this sense, the attribution of personalities to the protagonists facilitated endings more subtle-and more true to life-than a total victory for orthodox thought. Without characterisation, an ending which saw the heretic unconvinced would be deeply counter-intuitive and potentially destabilising for the imagined Catholic reader. When character was taken into account, the failure of dialogue to change the mind of a heretic could become as powerful a proof of Christian orthodoxy as success. 
Authenticity and pseudepigraphy

The use of revered figures like Athanasius highlights the extent to which these texts played to cultural notions which might be considered opposed to the whole project of inventing dialogue. Yet these texts were not external to the culture of patristic argumentation which developed in late antiquity. Nor were they simply parasitic upon it, even if some writers and texts came tantalisingly close to deliberate pseudepigraphy. The creative recasting of the teachings of past luminaries for present controversies was a key part of the argumentation from patristic, conciliar and scriptural precedents which dominated Christian debates from the early fifth century onwards. Expectations of adherence to strict standards of verbatim citation from received authorities were of course a central feature; clerics did not hesitate to accuse opponents of deviation from these agreed norms. Nevertheless, the mere act of exegesis gave invented speech an equally important role in the formation of Christian orthodoxy and literary culture in late antiquity. ${ }^{59}$ As Thomas Graumann (in particular) has cogently argued, the development of a canon of fathers simply created new topics for dispute. ${ }^{60}$ Thus, the exegetical practices of selection, interpretation and commentary inevitably produced new doctrines, even as those who employed them vigorously affirmed their faithful reproduction of received tradition. Similarly, in paraphrasing and creating the words of Athanasius or Augustine, heresiological dialogues both reflected and contributed to a Christian culture for which such patristic reinvention was fundamental.

The creative invention of speech such dialogue required allowed writers to remould the patristic past to suit the present. Through careful elaboration upon the doctrines these church fathers had professed, authors lent new developments the imprimatur 
of received authorities. Vigilius had his Athanasius attack numerous Arian enemies whose activities post-dated the bishop of Alexandria's death (c. 373), one of whom was Vigilius' contemporary. ${ }^{61}$ The topics Vigilius' Athanasius discussed and the arguments he presented were in line with contemporary African Nicene Trinitarian thought. Through the invented speech of the dialogue, these doctrines received the reflected glow of the bishop's formidable reputation.

In the original version of his dialogue, Vigilius of Thapsa was careful to signpost his own literary agency by the inclusion of a prologue. Not all writers were so conscientious. A number of fictitious late-antique Christian debate transcripts appear without authorial prefaces. Instead, their introductory sections seem designed to provide verisimilitude to what follows. They recount plausible narrative contexts, like individuals bumping into opponents in public or staging debates as breakout meetings at famous church councils. ${ }^{62}$ Vigilius' own dialogue was reformatted in this way not long after the circulation of the first edition..$^{63}$ Either Vigilius or another African Nicene cleric turned the debate into a one-on-one encounter between Athanasius and Arius at an invented church council called by Constantius II in Nicomedia in 338/339. ${ }^{64}$ To effect the switch, the author of the second edition added a historical introduction summarising the ecclesiastical politics of the years after Nicaea. He even created a fictitious sacra of the emperor convoking the council, which the judge character reads out at the beginning of the minutes. Even without the previous version, notable anachronisms would have prevented modern scholars from reading this text as a primary source for the early Arian Controversy. ${ }^{65}$ Nonetheless, as Averil Cameron has noted, the plausibility of the imaginary dialogues makes it difficult to judge whether many 'real' late-antiques debates actually happened. ${ }^{66}$ Readers in late antiquity and 
the early Middle Ages may have similarly struggled. Numerous Ps.-Augustinian and Ps.-Athanasian dialogues circulated amongst collections of those writers' genuine works.

The inclusion of explanatory prologues and fictitious interlocutors prevented other dialogues from drawing so directly upon the clout of past luminaries (and proofed them against accusations of forgery). Still, whomever authors chose as avatars, through the formatting alone they played on the authority of verbatim transcripts. By aping the minutes of church councils or public disputations, they made their texts look like the documentation crucial to the defence of particular doctrinal viewpoints. The inclusion of judges, auditors, hefty doses of legalese and even, in one case, a judicial subscription to the veracity of the transcript encouraged the same sense of reassuringly legalistic proof. ${ }^{67}$ Even the texts of more scrupulous writers tended to slide towards greater claims to authenticity in transmission. For example, in many of the earliest manuscript witnesses, the 'Orthodox' character of the Debate between the Luciferian and the Orthodox is replaced by Jerome himself. Of course, this alteration was not so far from the author's original intentions. Jerome had sought to make himself into a patristic authority by writing as 'Orthodox'; by the tenth century his success meant that the dialogue was more useful if he himself were in $i .^{68}$ It was the signal achievement of the Debate between the Luciferian and the Orthodox that Orthodox had become Jerome (and Jerome had become orthodox).

As a result of this tendency towards pseudepigraphy, both the peculiar placement and the contemporary agency of such texts can easily be lost in transmission. It is misleading to dismiss heresiological dialogues as acts of deception perpetuated on 
audiences too gullible to tell the real Athanasius or actual minutes from imitations. These texts both claimed to be patristic (or conciliar) and did not. To make clear to their audiences the contemporary relevance of the arguments of Athanasius or Augustine-and, perhaps more cynically, for the author to take credit-such writings could not wholly shed their literariness. The roles played by these texts within contemporary ecclesiastical politics and their reception by individuals known to their authors show that contemporary circumstances dictated their composition. Adam Schor has made the plausible suggestion that the publication of Theodoret's Eranistes in 447 was the catalyst for his confinement to his diocese. ${ }^{69}$ Jerome's Dialogue of Atticus and Critobulus had a similarly striking effect within a year of publication. Augustine wrote to Jerome in the summer of 416 to congratulate him: the Dialogue had apparently made it to imperial court at Ravenna and already begun to win over some of Pelagius' sympathizers. ${ }^{70}$ It was of course doubly in Augustine's interests to puff up the text's achievements, given his own position as a prominent anti-Pelagian campaigner and his need to placate his fellow Catholic heavyweight after their previous, bruising epistolary exchanges. ${ }^{71}$ Nevertheless, it is clear that the Dialogue was taken seriously even by Pelagius. Having (correctly) recognized that he was the implicit target, Pelagius felt the need to respond and to deny awareness of the doctrines articulated by his doppelganger, Critobulus. ${ }^{72}$ Through this virtual Christian debate, Jerome had taken a stand in a real one.

\section{Conclusion}

Heresiological dialogue texts have tended to be dismissed by modern scholars as a poor substitute for 'real' debate. The proliferation of examples of the genre in late antiquity suggests that it should be taken far more seriously. These dialogues gave 
Christian polemicists a means to articulate what they thought orthodoxy was, and clearly to distinguish it from other doctrinal positions which they perceived as heresy. Moreover, it gave them additional room to present their disputes as they themselves understood them, since they were able to characterize all of the antagonists themselves. These dialogues should not be taken as symptomatic of some closure of Christian discourse in late antiquity. In fact, they help to explain how controversial debates continued within a late-antique church in spite of increasingly elaborate appeals to earlier textual precedents and the intermittent efforts of secular and ecclesiastical authority figures to shut them down.

Fundamental to the utility of these dialogues was the paradoxical relationship they entertained with patristic authority and the broader ecclesiastical culture of verbatim citation from scriptural and exegetical texts which perpetuated it. These dialogues simultaneously traded on the clout of church fathers and flouted the rules of patristic citation by attributing to them new words and ideas. Crucial to the justification of such innovation was the deep-rooted plausibility which many of these dialogues sought to cultivate by their use of transcript formats, judges and biting quips. This sense of authenticity-which the likes of Vigilius and Jerome pointedly dismissed, but implicitly encouraged-allowed the authors of imaginary dialogues to produce new patristic precedents. If the fifth century did not see the end of Christian debate, it was (in part) because late-antique Christians were so effective at dressing up new disputes as old ones. Far from being a pale reflection of the real rough-and-tumble of public disputation, these imaginary dialogues made meaningful contributions to crucial confrontations over the nature of Christian truth and the identity of the Christians who taught it. 
${ }^{1}$ E.g. C. Humfress, 'Controversialist: Augustine in Combat', in M. Vessey (ed.) A Companion to Augustine (Chichester, 2012), pp. 323-35, at p. 330.

${ }^{2}$ E.g. B. D. Shaw, Sacred Violence: African Christians and Sectarian Hatred in the Age of Augustine (Cambridge, 2011), p. 12, p. 424.

${ }^{3}$ Cf. B. Voss, Der Dialog in der frühchristlichen Literatur (Munich, 1970), pp. 297-8.

${ }^{4}$ Useful surveys of early Christian dialogue: G. Bardy, 'Der Dialog (christlich)', in Reallexikon für Antike und Christentum, vol. 3 (Stuttgart, 1957), pp. 945-55; Voss, Der Dialog, esp. pp. 135-74, pp. 187-96, pp. 293-8; P.L. Schmidt, 'Zur Typologie und Literarisierung des frühchristlichen lateinischen Dialogs', in Christianisme et formes littéraires de l'Antiquité tardive en occident, Fondation Hardt pour l'étude de l'Antiquité classique: Entretiens 23 (Genève, 1977), pp. 101-90.

${ }^{5}$ S. Goldhill, 'Introduction: Why Don't Christians Do Dialogue?', in idem., The End of Dialogue in Antiquity (Cambridge, 2008), pp. 1-11, at p. 5. 
${ }^{6}$ R. Lim, Public Disputation, Power and Social Order in Late Antiquity, Transformation of the Classical Heritage 23 (Berkeley, CA, 1995); idem., 'Christians, Dialogues and Patterns of Sociability in Late Antiquity', in Goldhill (ed.) Dialogue, pp. 151-72.

${ }^{7}$ Av. Cameron, 'Can Christians Do Dialogue?', Studia Patristica 63 (2013), pp. 103-20; idem., Dialoguing in Late Antiquity, Hellenic Studies 65 (Cambridge, MA, 2014); P. Van Nuffelen, ‘The End of Open Competition? Religious Disputations in Late Antiquity', in P. Van Nuffelen and D. Engels (eds) Competition and Religion in Antiquity (Brussels, 2014), pp. 148-71.

${ }^{8}$ A favourite technique of Augustine: see e.g. Lim, Public Disputation, pp. 96-8.

${ }^{9}$ For editions and details of these dialogues: M. Geerard et al, Clavis patrum Graecorum (Turnhout, 1974-87), nos 5216, 5227-28, 2284-5; with P. Andrist, 'Les protagonistes égyptiens du débat apollinariste', Recherches augustiniennes et patristiques 34 (2005), pp. 63-141, at pp. 106-12.

${ }^{10}$ M.-P. Bussières, La littérature des questions et réponses dans l'antiquité profane et chrétienne: de l'enseignement à l'exégèse, Instrumenta Patristica et Mediaevalia 64 (Turnhout, 2013), with useful references. 
${ }^{11}$ Athanasius and Arius (and Arians): E. Dekkers, Clavis patrum Latinorum, $3^{\text {rd }}$ edn (Turnhout, 1995), nos 105, 807; Geerard et al, Clavis, no. 2250; Augustine and heretical opponents: Dekkers, Clavis, nos 366, 380, 808. Cyril and Nestorius: Geerard et al, Clavis, no. 5433.

${ }^{12}$ Rufinus, Libri Adamantii Origenis aduersus haereticos, esp. 1.13, 2.22, 5.28, ed. V. Buchheit, Studia et testimonia antiqua 1 (Munich, 1966), p. 15, pp. 49-50, pp. 99-100; Collatio Augustini cum Pascentio Ariano, ed. H. Müller, D. Weber and C. Weidmann, Veröffentlichungen der Kommission für die Herausgabe des Corpus der Lateinischen Kirchenväter 24 (Vienna, 2008); Arnobius, Conflictus cum Serapione, ed. K.-D. Daur, CCSL 25A (1992), pp. 43-173; Vigilius, Contra Arianos, Sabellianos, Photinianos dialogus, 1.1, PL 62, cols 179D-181B. Vigilius' Dialogus is in dire need of the critical edition in preparation for CCSL by Pierre-Marie Hombert; in lieu of that edition, I cite from PL.

${ }^{13}$ E.g. Theodoret, Eranistes, 1, 2, ed. G.H. Ettlinger (Oxford, 1975), p. 111, pp. 187-8; Vigilius, Dialogus, 2.1, PL 62, cols 197C-D; also Hieronymus, Altercatio Luciferiani et Orthodoxi, c. 1, ed. A. Canellis, CCSL 79B (2000), p. 6.

${ }^{14}$ Timewasting: e.g. Vigilius, Dialogus, 1.16, 1.26, PL 62, col. 191C, col. 198A; Hieronymus, Dialogus aduersus Pelagianos, 1.21, ed. C. Moreschini, CCSL 80 (1990), p. 27. Blasphemy: e.g. Theodoret, Eranistes, 1, ed. Ettlinger, p. 82, pp. 109-11; Hieronymus, 
Dialogus, 1.6, ed Moreschini, p. 10. Irrelevance: e.g. Theodoret, Eranistes, 2, ed. Ettlinger, p. 117; Hieronymus, Altercatio, c. 11, ed. Canellis, p. 31; idem., Dialogus, 3.1, ed. Moreschini, p. 98.

${ }^{15}$ Lim, 'Patterns of sociability', e.g. pp. 152-3.

${ }^{16}$ Esp. J. König, 'Sympotic Dialogue in the First to Fifth Centuries CE', in Goldhill (ed.) Dialogue, pp. 85-114, at p. 92; see also the papers by Ford, Long and Schofield. See too Cameron, Dialoguing, pp. 12-13 and Van Nuffelen, 'Religious Disputations', p. 148.

${ }^{17}$ Cf. J. König, Saints and Symposiasts: The Literature of Food and the Symposium in GrecoRoman and Early Christian Literary Culture (Cambridge, 2012), pp. 41-59, pp. 103-20, pp. 203-8; also A. Ford, 'The Beginnings of Dialogue: Socratic Dialogues and FourthCentury Prose', in Goldhill (ed.) Dialogue, pp. 29-44, at pp. 31-3.

${ }^{18}$ Cf. C. Humfress, Orthodoxy and the Courts in Late Antiquity (Oxford, 2007), pp. 219-20 on late-antique heresiology as monologic.

${ }^{19}$ Cf. Lim, 'Patterns of Sociability', pp. 157-8, p. 165. 
${ }^{20}$ König, Saints and Symposiasts.

${ }^{21}$ Vigilius, Dialogus, preface, PL 62, cols 179C-180C: Dum mecum de fidei ueritate diu multumque tractarem, atque Scripturae consideratione requirerem quonam modo multiplices et numerosas haereticorum quaestiones, responsionis breuitate refellerem, (...) utile hoc et ualde commodum apparuit, ut uniuscuiusque haeretici personam cum sui dogmatis professionibus, quasi praesentes cum praesentibus agerent introducerem. Et ne singulorum prosecutiones in dubium nullo examinante uenirent, arbitrum quemdam nomine Probum, auctoritate judiciaria functum interesse feci, quo de singulis quibusque probabiliter discernente, impiae pravitatis cassaretur intentio. Sabellium ergo, Photinum, Arium, atque ad nostras partes Athanasium introduxi, ut ueritas, summo confligentium certamine eliquata, ad omnium notitiam perveniret,

${ }^{22}$ Schmidt, 'Zur Typologie’, pp. 149-50 for extracts.

${ }^{23}$ For an introduction: Av. Cameron, 'How to Read Heresiology', Journal of Medieval and Early Modern Studies 33 (2003), pp. 471-92. 
${ }^{24}$ I. Sandwell, Religious Identity in Late Antiquity: Greeks, Jews and Christians in Antioch (Cambridge, 2007); T. Sizgorich, Violence and Belief in Late Antiquity: Militant Devotion in Christianity and Islam (Philadelphia, PA, 2009), pp. 1-80; É. Rebillard, Christians and Their Many Identities in Late Antiquity, North Africa, 200-450 CE (Ithaca, NY, 2012).

${ }^{25}$ Lim, 'Patterns of Sociability', p. 171.

${ }^{26}$ Theodoret, Eranistes, prologue, ed. Ettlinger, p. 62; Hieronymus, Altercatio, esp. c. 4, c. 11, cc. 13-14, ed. Canellis, pp. 9-10, 31-2, 34-8; Lim, 'Patterns of Sociability', pp. 166-8.

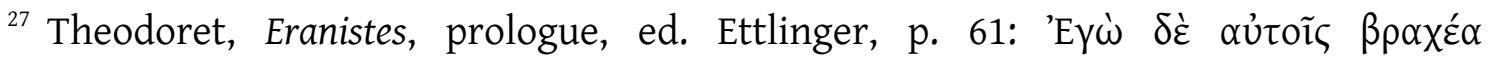

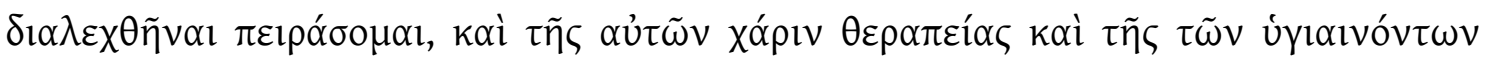

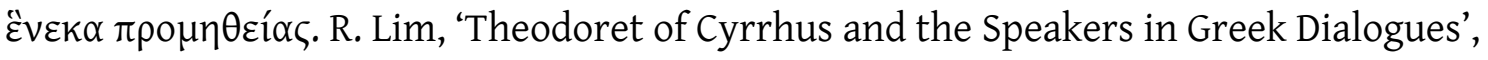
Journal of Hellenic Studies 111 (1991), pp. 181-2; Cameron, Dialoguing, pp. 46-7 with n. 37.

${ }^{28}$ Schmidt, 'Zur Typologie', pp. 116-7, 148-9.

${ }^{29}$ See above, n. 2 . 
${ }^{30}$ Preaching as onerous: e.g. R. Van Dam, 'Bishops and Society', in A. Casiday and F.W. Norris, The Cambridge History of Christianity, Vol. 2: Constantine to c. 600 (Cambridge, 2007), pp. 343-66, at pp. 344-5.

${ }^{31}$ Y. Papadoyannakis, 'Instruction by Question and Answer: The Case of Late Antique and Byzantine Erotapokriseis', in S.F. Johnson, Greek Literature in Late Antiquity: Dynamism, Didacticism, Classicism (Aldershot, 2006), pp. 91-105.

${ }^{32}$ Lim, Public Disputation, p. 102.

${ }^{33}$ E.g. Theodoret, Eranistes, 1, 2, 3, ed. Ettlinger, pp. 109-11, pp. 184-7, pp. 247-53; Vigilius, Dialogus, 3.9-10, PL 62, 235C-236B.

${ }^{34}$ Theodoret, Eranistes, 1, ed. Ettlinger, pp. 63-8.

${ }^{35}$ For shrewd analysis of the receipt of polemical texts by their victims: R. Miles, “"Let's (not) Talk About It": Augustine and the Control of Epistolary Dialogue', in Goldhill (ed.) Dialogue, pp. 135-48, at pp. 139-40; J.V. Ebbeler, Disciplining Christians: Correction and Community in Augustine's Letters (Oxford, 2012), pp. 75-189. 
${ }^{36}$ Theodoret, Eranistes, prologue, ed. Ettlinger, p. 61.

${ }^{37}$ Y.-M. Perrin, 'The Limits of the Heresiological Ethos in Late Antiquity', in D.M. Gwynn and S. Bangert (eds) Religious Diversity in Late Antiquity, Late Antique Archaeology 6 (Leiden, 2010), pp. 201-27.

${ }^{38}$ Av. Cameron, 'Apologetics in the Roman Empire-A Genre of Intolerance?', in J.-M. Carrié and R. Lizzi Testa, 'Humana sapit': études d'antiquité tardive offerts à Lellia Cracco Ruggini, Bibliothéque de l'Antiquité Tardive 3 (Turnhout, 2002), pp. 219-27.

${ }^{39}$ For all of this: Basil, Epistulae, 135, ed. Y. Courtonne, 3 vols (Paris, 1957-66), II, pp. 4951; with Schmidt, 'Zur Typologie', pp. 150-1; Cameron, Dialoguing, pp. 3-4.

${ }^{40}$ E.g. Ford, 'Socratic Dialogues', pp. 34-5, p. 42.

${ }^{41}$ See best: Ebbeler, Disciplining Christians. 
${ }^{42}$ Hieronymus, Dialogus, prologue, paragraph 2, ed. Moreschini, pp. 4-5. On the misleading modern title: B. Jeanjean, 'Le Dialogus Attici et Critobuli de Jérôme et la prédication pélagienne en Palestine entre 411 et 415', in A. Cain and J. Lössl (eds) Jerome of Stridon: His Life, Writings and Legacy (Farnham, 2009), pp. 59-71, at p. 59, p. 64 with n. 19.

${ }^{43}$ Fulgentius, Contra Fabianum fragmenta, fragment 14.1, ed. J. Fraipont, CCSL 91A (1968), p. 783: Ego igitur illa quae tibi uisum est sub nomine meo falsis gestis inserere, nec sensi, nec dixi.

${ }^{44}$ See Miles, 'Epistolary Dialogue', pp. 136-7, on Augustine’s use of this methodology.

${ }^{45}$ Nestorius, Book of Heracleides, trans. G.R. Driver and L. Hodgson (Oxford, 1925); G.H. Ettlinger, Theodoret of Cyrus: Eranistes, The Fathers of the Church 106 (Washington, D.C., 2003), pp. 2-3. Theodoret also described him as the 'Polymorph'.

${ }^{46}$ Ettlinger, Theodoret, pp. 6-10; A.M. Schor, Theodoret's People: Social Networks and Religious Conflict in Late Roman Syria, Transformation of the Classical Heritage 48 (Berkeley, CA, 2011), p. 124, pp. 184-5; Cameron, Dialoguing, p. 47. 
${ }^{47}$ Hieronymus, Dialogus, prologue, at lines 22-6, ed. Moreschini, pp. 4-5: unde ut omnibus approbarem me non odisse homines, sed errores, nec aliquorum infamiam quaerere, (...) attici et critobuli nomina posui, per quos et nostra pars et aduersariorum quid sentiret, expromerem.

${ }^{48}$ Introduced at Hieronymus, Altercatio, cc. 1-2, ed. Canellis, pp. 5-6.

${ }^{49}$ Theodoret, Eranistes, prologue, ed. Ettlinger, p. 62.

${ }^{50}$ See e.g. Cyril, Quod unus sit Christus, 716d, ed. G.M. de Durand, Sources chrétiennes 97 (Paris, 1964), p. 310.

${ }^{51}$ Vigilius, Dialogus, 1.1-3, PL 62, cols 179D-182B; P. Guidi, Vigilio di Tapso: Contro gli Ariani, Testi Patristici 184 (Rome, 2005), pp. 55-6, nn. 1-3.

${ }^{52}$ Vigilius, Dialogus, 3, PL 62, cols 229C-238A.

${ }^{53}$ Theodoret, Eranistes, 1, ed. Ettlinger, pp. 63-7; Vigilius, Dialogus, 1.2, 1.12, PL 62, cols 181C-D, cols 188C-D. 
${ }^{54}$ Hieronymus, Altercatio, cc. 14-16, ed. Canellis, pp. 36-42.

${ }^{55}$ Hieronymus, Altercatio, c. 28, ed. Canellis, pp. 68-9: Non solum aestimes te uicisse: uicimus. Vterque nostrum palmam refert: tu mei et ego erroris. (...) Vnum autem tibi confiteor, quia mores meorum apprime noui, facilius eos uinci posse quam persuaderi.

${ }^{56}$ Vigilius, Dialogus, 2.50, PL 62, col. 230B.

${ }^{57}$ Ps.-Athanasius, Disputatio contra Arium, PG 28, pp. 500-1.

${ }^{58}$ A.H. Merrills and R. Miles, The Vandals (Chichester, 2010), pp. 177-203.

${ }^{59}$ A point nicely made by J. Kecskeméti, 'Exégèse chrysostomienne et exégèse engagée', Studia Patristica 22 (1989), pp. 136-47, at p. 136.

${ }^{60} \mathrm{~T}$. Graumann, 'The Conduct of Theology and the "Fathers of the Church", in P. Rousseau (ed.) A Companion to Late Antiquity (Chichester, 2009), pp. 539-55. 
${ }^{61}$ Vigilius, Dialogus, 2.45, 2.50, PL 62, cols 226D-227A, 229D-230A.

${ }^{62}$ Hieronymus, Altercatio, cc. 1-2, ed. Canellis, pp. 5-6; Ps.-Athanasius, Disputatio, PG 28, p. 440.

${ }^{63}$ Ps.-Vigilius, Dialogus, PL 62, pp. 155-80.

${ }^{64}$ Using Rufinus, Historia ecclesiastica, 10.12, ed. T. Mommsen, Die griechischen christlichen Schriftsteller der ersten drei Jahrhunderte 9, 2 vols (1903-8), II, pp. 976-8 (who had Arius unhistorically outlive Constantine).

${ }^{65}$ Ps.-Vigilius, Dialogus 1.1-3, PL 62, cols 155A-157A. The sacra contains verbal borrowings from edicts promulgated by the Vandal King Huneric in 483 and 484 (see Victor of Vita, Historia persecutionis Africanae prouinciae, 2.39, 3.3, ed. S. Lancel [Paris, 2002], p. 139, p. 175).

${ }^{66}$ Cameron, Dialoguing, p. 18, p. 25, p. 27. 
${ }^{67}$ Judges: above, n. 12. Auditors: e.g. Rufinus, Libri Adamantii Origenis, 1.1, 1.13, 2.17, 2.19, ed. Buchheit, p. 2, p. 15, p. 42, p. 46; Vigilius, Dialogus, 2.6, 2.20, 2.22, PL 62, 201D, 210C, 211C. Legalese: Schmidt, 'Zur Typologie', pp. 128-34. Judicial subscription: Collatio cum Pascentio, c. 19, ed. Müller, Weber and Weidmann, p. 118.

${ }^{68}$ A. Canellis, Altercatio Luciferiani et Orthodoxi, CCSL 79B (Turnhout, 2000) p. 6, note for line 18 , with p. 3.

${ }^{69}$ Schor, Theodoret's People, pp. 122-8.

${ }^{70}$ Augustine, Epistulae, 19*.2, ed. J. Divjak, CSEL 88 (Vienna, 1981), p. 91.

${ }^{71}$ Miles, 'Epistolary Dialogue', pp. 141-8; Ebbeler, Disciplining Christians, pp. 101-50.

${ }^{72}$ Augustine, Epistulae, 19*.2, ed. Divjak, p. 91; pace Jeanjean, 'Le Dialogus', p. 95. 